\title{
ARTICLE
}

\section{Safety assessment of transportation and interim storage of rice straw contaminated by radioactive cesium due to the sever e accident at the Fukushima Nuclear Plant}

\author{
Seiji Takeda* and Hideo Kimura \\ Japan Atomic Energy Agency, 2-4 Shirakata, Tokai-mura, Naka-gun, Ibaraki-ken, 319-1195, J apan
}

\begin{abstract}
Radioactive cesium in the rice straw was detected to be maximum value of $690,000 \mathrm{~Bq} / \mathrm{kg}$ after the severe accident of Fukushima Nuclear Plant. The straw was distributed to the market to feed beef cattle. The radiation exposure dose for the dairy farmer should be decreased based on prompt and suitable treatment such as moving and storage of contaminated straw. In order to provide the Japanese government with the technical information of the treatment, dose analyses for the scenarios on transportation and interim storage of contaminated straw were conducted in this study. As a result for transportation scenario, in the case of radioactive cesium concentration of $700,000 \mathrm{~Bq} / \mathrm{kg}$, the annual dose for the transportation worker from remote place is calculated to be $1.3 \mathrm{mSv} / \mathrm{y}$, exceeding effective dose criterion of $1 \mathrm{mSv} / \mathrm{y}$ for a worker. Therefore, it is suggested that the worker needs the measures to decrease the dose for the dominant external exposure pathway, namely, limiting transit time, reducing the straw volume and utilizing radiation shielding materials. The calculated results for interim storage scenario indicate that the distance to suppress the dose for an outside worker within $1 \mathrm{mSv} / \mathrm{y}$ is $10 \mathrm{~m}$ for $100,000 \mathrm{~Bq} / \mathrm{kg}$ and $30 \mathrm{~m}$ for $500,000 \mathrm{~Bq} / \mathrm{kg}$ and $700,000 \mathrm{~Bq} / \mathrm{kg}$.
\end{abstract}

Keywords: safety assessment; rice straw; radioactive cesium; dose; external exposure; transportation; interim storage; F ukushima Nuclear Plant; severe accident

\section{Introduction}

In the northeastern area, the rice straws, which were dried in a farmland at the severe accident of the Fukushima Nuclear Plant, were contaminated by radioactive cesium $\left({ }^{134} \mathrm{Cs}\right.$ and $\left.{ }^{137} \mathrm{Cs}\right)$. The activity concentration of radioactive cesium in the rice straw was detected to be maximum value of $690,000 \mathrm{~Bq} / \mathrm{kg}$ [1] Since the contaminated rice straw was distributed to the market to feed beef cattle, the Japanese government needed to attain a decrease in radiation exposure dose of the dairy farmer holding it. For the purpose, it is necessary to decide the criteria of transportation and interim storage of the straw. In order to provide the technical information for making the decision, dose analyses for the scenarios on transportation and interim storage of the rice straw were conducted in this study.

\section{Dose estimation for transportation scenario}

\subsection{Analytical method}

\subsubsection{Scenario description}

Table 1 shows four transportation scenarios characterized with the information on transport situation

*Corresponding author. Email: takeda.seiji@jaea.go.jp and shapes of collected straw based on hearing investigation to the dairy farmer. There are two kinds of transport situation, namely, transportation to neighboring farmland by a light truck and transportation from remote place by a heavy-duty truck. The scenarios are considered two shapes of collected straw, rolled straw (cylinder) and compact straw (rectangular parallelepiped). It is assumed that a worker engaged in a series of works such as loading, transportation and unloading. The external exposure pathways shown in Table1 are selected in dose calculation. However, the other pathways on inhalation of contaminated dust and ingestion of contaminated materials for workers are excluded, because their doses of similar pathways estimated for derivation of clearance levels of ${ }^{134} \mathrm{Cs}$ and ${ }^{137} \mathrm{Cs}$ are two orders of magnitude lower than that of the external exposure pathway [2]. Exposure time for each external exposure pathway is assumed from working hours expected actually.

\subsubsection{Effective dose conversion factor of external exposure pathway}

Effective dose conversion factor $(\mu \mathrm{Sv} / \mathrm{h}$ per $\mathrm{Bq} / \mathrm{g})$ of each external exposure pathway for unit concentration of radionuclide in the straw is estimated using QAD-CGGP2R [3]. Table 2 shows the conditions of radiation sources and calculated effective dose 
Table 1. Transportation scenario and exposure pathways.

\begin{tabular}{|c|c|c|c|}
\hline \multicolumn{2}{|c|}{ Type of transportation scenario } & A series of works (external exposure pathways) & $\begin{array}{c}\text { Working hours per } \\
\text { a transportation }\end{array}$ \\
\hline \multirow{9}{*}{$\begin{array}{l}\text { Transportation } \\
\text { to neighboring } \\
\text { farmland by a } \\
\text { light truck*1 }\end{array}$} & \multirow{5}{*}{$\begin{array}{l}\text { Rolled straw*2 } \\
\text { (Scenario I-A) }\end{array}$} & External exposure in loading and unloading rolled straws by an agricultural machine (No.1) & 3 \\
\hline & & External exposure in treatment of rolled straws by hands (No.2) & 1 \\
\hline & & External exposure from piled straws during working of No.1\&2 (No.3) & 4 \\
\hline & & Transportation of rolled straws by a light truck (No.4) & 1 \\
\hline & & External exposure in working on rolled straws piled over the platform of light truck (No.5) & 0.5 \\
\hline & \multirow{4}{*}{$\begin{array}{c}\text { Compact straw } * 2 \\
(\text { Scenario I-B })\end{array}$} & External exposure in loading and unloading compact straws by hands (No.6) & 4 \\
\hline & & External exposure from piled straws during working of No.6 (No.7) & 4 \\
\hline & & Transportation of compact straws by a light truck (No.8) & 1 \\
\hline & & External exposure in working on compact straws piled over the platform of light truck (No.9) & 0.5 \\
\hline \multirow{9}{*}{$\begin{array}{l}\text { Transportation } \\
\text { from remote } \\
\text { place to the } \\
\text { northeastern } \\
\text { area in Japan } \\
\text { by a heavy- } \\
\text { duty truck }\end{array}$} & \multirow{5}{*}{$\begin{array}{c}\text { Rolled straw } \\
\text { (Scenario II-A) }\end{array}$} & External exposure in loading and unloading rolled straws by an agricultural machine (No.1) & 3 \\
\hline & & External exposure in treatment of rolled straws by hands (No.2) & 1 \\
\hline & & External exposure from piled straws during working of No.1\&2 (No.3) & 4 \\
\hline & & Transportation of rolled straws by a heavy-duty truck (No.10) & 12 \\
\hline & & External exposure in working on rolled straws piled over the platform of heavy-duty truck (No.11) & 0.5 \\
\hline & \multirow{4}{*}{$\begin{array}{l}\text { Compact straw } \\
\text { (Scenario II-B) }\end{array}$} & External exposure in loading and unloading compact straws by hands (No.6) & 4 \\
\hline & & External exposure from piled straws during working of No.6 (No.7) & 4 \\
\hline & & Transportation of compact straws by a heavy-duty truck (No.12) & 12 \\
\hline & & External exposure in working on compact straws piled over the platform of heavy-duty truck (No.13) & 0.5 \\
\hline
\end{tabular}

(*1) In transportation to neighboring farmland, the dose of worker is calculated from contaminated straw without a contribution of contaminated environment. (*2) The shapes of collected straw are divided into rolled straw (cylinder) and compact straw (rectangular parallelepiped). Additionally, there are large size (diameter- $1.2 \mathrm{~m} \times$ height $-1.2 \mathrm{~m}$, density $: 0.18 \mathrm{~g} / \mathrm{cm}^{3}$ ) and small size (diameter- $0.8 \mathrm{~m}$ ×height $-0.8 \mathrm{~m}$, density $: 0.37 \mathrm{~g} / \mathrm{cm}^{3}$ ) of rolled straw. In the scenario of rolled straw, the representative size is determined from the higher dose result of external exposure calculated between two sizes of rolled straw preliminarily.

Table 2. Effective dose conversion factors of external exposure pathways estimated using QAD-CGGP2R.

\begin{tabular}{|c|c|c|c|c|c|}
\hline \multirow{2}{*}{ No } & \multirow{2}{*}{$\begin{array}{l}\text { Conditions to estimate effective dose conversion factor of } \\
\text { external exposure pathway }(\mu \mathrm{Sv} / \mathrm{h} \text { per Bq} / \mathrm{g})\end{array}$} & \multirow{2}{*}{\begin{tabular}{|l|} 
Cs-134 \\
Cs-137 \\
\end{tabular}} & \multirow{2}{*}{$\mathrm{N}$} & \multirow{2}{*}{$\begin{array}{l}\text { Conditions to estimate effective dose conversion factor of } \\
\text { external exposure pathway }(\mu \mathrm{Sv} / \mathrm{h} \text { per } \mathrm{Bq} / \mathrm{g})\end{array}$} & \multirow{2}{*}{\begin{tabular}{|l|} 
Cs-134 \\
Cs-137 \\
\end{tabular}} \\
\hline & & & & & \\
\hline \multirow{2}{*}{$1 *$} & $\begin{array}{l}\text { Source size :diameter- } 1.2 \mathrm{~m} \times \text { height }-1.2 \mathrm{~m} \text { (large rolled straw, cylinder) } \\
\cdot \text { Weight }: 250 \mathrm{~kg} \text { Density }: 0.18 \mathrm{~g} / \mathrm{cm}^{3}\end{array}$ & $7.2 \mathrm{E}-03$ & \multirow[b]{2}{*}{8} & \multirow{2}{*}{$\begin{array}{l}\text { Source size } 2.0 \mathrm{~m} \times 1.6 \mathrm{~m} \times 2.4 \mathrm{~m}(\text { compact straws), considering } \\
\text { radiation shielding with iron of } 3 \mathrm{~mm} \text { thick } \\
\cdot \text { Weight }: 2,000 \mathrm{~kg} \quad \text { Density }: 0.26 \mathrm{~g} / \mathrm{cm}^{3} \\
\text { Evaluation point }: 0.5 \mathrm{~m} \text { from the center of a area }(1.6 \mathrm{~m} \times 2.4 \mathrm{~m})\end{array}$} & $1.4 \mathrm{E}-01$ \\
\hline & $\begin{array}{l}\text { Evaluation point } 2 \mathrm{~m} \text { from the cylindrical side center It sets up from } \\
\text { the length of the arm of a common front loader.) }\end{array}$ & $2.6 \mathrm{E}-03$ & & & $5.0 \mathrm{E}-02$ \\
\hline \multirow[b]{2}{*}{ 2* } & \multirow{2}{*}{$\begin{array}{l}\text { Source size :diameter- } 1.2 \mathrm{~m} \times \text { height- } 1.2 \mathrm{~m} \text { (large rolled straw, cylinder) } \\
\cdot \text { Weight }: 250 \mathrm{~kg} \quad \text { Density }: 0.18 \mathrm{~g} / \mathrm{cm}^{3} \\
\text { Evaluation point }: 0.5 \mathrm{~m} \text { away from the cylindrical side center }\end{array}$} & 3.7E-02 & \multirow{2}{*}{9} & \multirow{2}{*}{$\begin{array}{l}\text { Source size }: 2.0 \mathrm{~m} \times 1.6 \mathrm{~m} \times 2.4 \mathrm{~m}(\text { compact straws }) \\
\cdot \text { Weight }: 2,000 \mathrm{~kg} \quad \text { Density }: 0.26 \mathrm{~g} / \mathrm{cm}^{3} \\
\text { Evaluation point }: 1 \mathrm{~m} \text { from the center of a area }(2.0 \mathrm{~m} \times 1.6 \mathrm{~m})\end{array}$} & 7.0E-02 \\
\hline & & $1.4 \mathrm{E}-02$ & & & $2.6 \mathrm{E}-02$ \\
\hline \multirow{2}{*}{$3^{*}$} & \multirow{2}{*}{$\begin{array}{l}\text { Source size }: 7.2 \mathrm{~m} \times 6.0 \mathrm{~m} \times 2.4 \mathrm{~m}(6 \times 5 \times 2 \text { large rolled straws are pilled.) } \\
\cdot \text { Weight : } 18,700 \mathrm{~kg} \text { Density }: 0.18 \mathrm{~g} / \mathrm{cm}^{3} \\
\text { Evaluation point }: 5 \mathrm{~m} \text { from the center of a area }(7.2 \mathrm{~m} \times 2.4 \mathrm{~m}) \text {, and } 1 \mathrm{~m} \text { in } \\
\text { height from the ground }\end{array}$} & $3.0 \mathrm{E}-02$ & \multirow{2}{*}{$10 *$} & \multirow{2}{*}{$\begin{array}{l}\text { Source size }: 4.7 \mathrm{~m} \times 2.4 \mathrm{~m} \times 2.4 \mathrm{~m} \text { (small rolled straws), } \\
\text { considering radiation shielding with iron of } 3 \mathrm{~mm} \text { thick } \\
\cdot \text { Weight }: 10,000 \mathrm{~kg} \quad \text { Density }: 0.37 \mathrm{~g} / \mathrm{cm}^{3} \\
\text { Evaluation point }: 0.5 \mathrm{~m} \text { from the center of a area }(2.4 \mathrm{~m} \times 2.4 \mathrm{~m})\end{array}$} & 2.0E-01 \\
\hline & & $1.1 \mathrm{E}-02$ & & & 7.3E-02 \\
\hline \multirow[b]{2}{*}{ 4* } & \multirow{2}{*}{$\begin{array}{l}\text { Source size }: 1.4 \mathrm{~m} \times 1.6 \mathrm{~m} \times 2.4 \mathrm{~m}(\text { small rolled straws), considering } \\
\text { radiation shielding with iron of } 3 \mathrm{~mm} \text { thick } \\
\cdot \text { Weight }: 2,000 \mathrm{~kg} \quad \text { Density }: 0.37 \mathrm{~g} / \mathrm{cm}^{3} \\
\text { Evaluation point }: 0.5 \mathrm{~m} \text { from the center of a area }(1.6 \mathrm{~m} \times 2.4 \mathrm{~m}) \\
\end{array}$} & $1.6 \mathrm{E}-01$ & \multirow{2}{*}{$11 *$} & \multirow{2}{*}{$\begin{array}{l}\text { Source size }: 4.7 \mathrm{~m} \times 2.4 \mathrm{~m} \times 2.4 \mathrm{~m}(\text { small rolled straws }) \\
\cdot \text { Weight }: 10,000 \mathrm{~kg} \quad \text { Density }: 0.37 \mathrm{~g} / \mathrm{cm}^{3} \\
\text { Evaluation point }: 1 \mathrm{~m} \text { from the center of a area }(4.7 \mathrm{~m} \times 2.4 \mathrm{~m})\end{array}$} & $1.8 \mathrm{E}-01$ \\
\hline & & $5.8 \mathrm{E}-02$ & & & $6.4 \mathrm{E}-02$ \\
\hline \multirow{2}{*}{$5^{*}$} & \multirow{2}{*}{$\begin{array}{l}\text { Source size }: 2.9 \mathrm{~m} \times 1.6 \mathrm{~m} \times 2.4 \mathrm{~m} \text { (large rolled straws) } \\
\cdot \text { Weight } 2,000 \mathrm{~kg} \quad \text { Density }: 0.18 \mathrm{~g} / \mathrm{cm}^{3} \\
\text { Evaluation point }: 1.0 \mathrm{~m} \text { from the center of a area }(2.9 \mathrm{~m} \times 1.6 \mathrm{~m})\end{array}$} & 7.3E-02 & \multirow{2}{*}{12} & & $1.8 \mathrm{E}-01$ \\
\hline & & $2.7 \mathrm{E}-02$ & & & $6.4 \mathrm{E}-02$ \\
\hline \multirow[b]{2}{*}{5} & \multirow{2}{*}{$\begin{array}{l}\text { Source size }: 0.3 \mathrm{~m} \times 0.4 \mathrm{~m} \times 0.8 \mathrm{~m} \text { (compact straw) } \\
\cdot \text { Weight }: 25 \mathrm{~kg} \quad \text { Density }: 0.26 \mathrm{~g} / \mathrm{cm}^{3} \\
\text { Evaluation point }: 0.01 \mathrm{~m} \text { from the center of a area }(0.8 \mathrm{~m} \times 0.4 \mathrm{~m})\end{array}$} & $1.0 \mathrm{E}-01$ & \multirow{2}{*}{13} & \multirow{2}{*}{$\begin{array}{l}\text { Source size }: 6.7 \mathrm{~m} \times 2.4 \mathrm{~m} \times 2.4 \mathrm{~m}(\text { compact straws }) \\
\cdot \text { Weight }: 10,000 \mathrm{~kg} \quad \text { Density }: 0.26 \mathrm{~g} / \mathrm{cm}^{3} \\
\text { Evaluation point }: 1 \mathrm{~m} \text { from the center of a area }(6.7 \mathrm{~m} \times 2.4 \mathrm{~m})\end{array}$} & $1.7 \mathrm{E}-01$ \\
\hline & & $3.7 \mathrm{E}-02$ & & & $6.3 \mathrm{E}-02$ \\
\hline \multirow{2}{*}{7} & \multirow{2}{*}{$\begin{array}{l}\text { Source size } 3.2 \mathrm{~m} \times 1.2 \mathrm{~m} \times 1.5 \mathrm{~m}(3 \times 4 \times 5 \text { compact straws are pilled. }) \\
\cdot \text { Weight }: 1,500 \mathrm{~kg} \text { Density }: 0.26 \mathrm{~g} / \mathrm{cm}^{3} \\
\text { Evaluation point } 5 \mathrm{~m} \text { from the center of a area }(3.2 \mathrm{~m} \times 1.5 \mathrm{~m}) \text {, and } 1 \mathrm{~m} \text { in } \\
\text { height from the ground }\end{array}$} & $7.9 \mathrm{E}-03$ & \multirow{2}{*}{\multicolumn{3}{|c|}{$\begin{array}{l}\text { (*) In the pathway treating rolled straw, the representative size shown in } \\
\text { Table } 2 \text { is determined from the higher effective dose conversion factor } \\
\text { calculated between large size and small size of rolled straw preliminarily. }\end{array}$}} \\
\hline & & $2.9 \mathrm{E}-03$ & & & \\
\hline
\end{tabular}

conversion factors (No.1-13). It is assumed that the distribution of radionuclide concentration inside the straw is uniform. The elemental composition of straw to set up linear attenuation coefficient is standardized from the data measured as organic and inorganic elemental composition [4-6], respectively. The buildup factor of air is used conservatively [7].

\subsection{Analytical result for transportation scenario}

The result of dose estimation for four types of transportation scenario (scenario I-A, I-B, II-A and II-B) is shown in Table 3 . The value in Table 3 is the estimated dose for radioactive cesium concentration of $10,000 \mathrm{~Bq} / \mathrm{kg}$ per a transportation. The existence ratio of ${ }^{134} \mathrm{Cs} /{ }^{137} \mathrm{Cs}=1.0$ is conservatively assumed regardless of 
decreasing of ${ }^{134} \mathrm{Cs}$ (half-life 2y) with decay, for which the effective dose conversion factors of external exposure pathway are higher than for ${ }^{137} \mathrm{Cs}$. In the case of transportation to neighboring farmland, the dose for the compact straws (scenario I-B) is higher than that for the rolled straws (scenario I-A), because of the higher dose for loading and unloading by hands than by an agricultural machine. The doses for transportation from remote place (scenario II-A and II-B) are about 5 times higher than that for transportation to neighboring farmland (scenario I-B).

Table 3. Dose estimated for transportation scenario.

\begin{tabular}{|c|c|c|}
\hline \multicolumn{2}{|c|}{ Type of transportation scenario } & Effective dose $(\mathrm{mSv})^{*}$ \\
\hline Transportation to & \begin{tabular}{|c|} 
Rolled straw \\
(Scenario I-A)
\end{tabular} & 0.0026 \\
\hline $\begin{array}{l}\text { neignooring larmiand by a } \\
\text { light truck }\end{array}$ & $\begin{array}{l}\text { Compact straw } \\
\text { (Scenario I-B) }\end{array}$ & 0.0041 \\
\hline $\begin{array}{l}\text { Transportation from } \\
\text { remote place to the }\end{array}$ & $\begin{array}{c}\text { Rolled straw } \\
\text { (Scenario II-A) }\end{array}$ & 0.018 \\
\hline $\begin{array}{l}\text { northeastern area in Japan } \\
\text { by a heavy-duty truck }\end{array}$ & $\begin{array}{l}\text { Compact straw } \\
\text { (Scenario II-B) }\end{array}$ & 0.018 \\
\hline
\end{tabular}

Table 4 shows the number of times of transportation to restrict the annual dose to less than $1 \mathrm{mSv} / \mathrm{y}$ for four cesium concentration cases of $10,000 \mathrm{~Bq} / \mathrm{kg}$, $100,000 \mathrm{~Bq} / \mathrm{kg}, 500,000 \mathrm{~Bq} / \mathrm{kg}$ and $700,000 \mathrm{~Bq} / \mathrm{kg}$. In the case of $100,000 \mathrm{~Bq} / \mathrm{kg}$, the number is restricted to be 24 times for transportation of compact straws to neighboring farmland and to be 5 times for transportation from remote place. In the case of $700,000 \mathrm{~Bq} / \mathrm{kg}$, the annual dose for the transportation worker from remote place is calculated to be $1.3 \mathrm{mSv} / \mathrm{y}$, exceeding effective dose criterion of $1 \mathrm{mSv} / \mathrm{y}$ for engaging in a treatment of materials contaminated by the severe accident [8]. Therefore, it is suggested that the worker needs the measures to decrease the dose for the dominant external exposure pathway, namely, limiting transit time, reducing the straw volume and utilizing radiation shielding materials.

\section{Dose estimation for inter im storage scenario}

\subsection{Analytical method}

When the contaminated rice straws are stored temporally, the effect of direct and skyshine radiation scattered in the air and ground for an outdoor worker near the interim storage place (interim storage scenario) should be estimated. In order to investigate the effect of annual dose for the outdoor worker, the dose calculation due to direct and skyshine radiation is carried out using MCNP-4C [9]. It is assumed that 60 large rolled straws, which leads to the maximum of source strength among three types of straw, are pilled in the storage place. Figure 1 shows the dose calculation system for interim storage scenario under the conditions of both one layer and two layers source, which are composed of 6x10x1 and of $5 \times 6 \times 2$ rolled straws, respectively. The distance from the source to an evaluation point changes in the range of $2 \mathrm{~m}$ to $100 \mathrm{~m}$. The exposure time of $2,000 \mathrm{~h} / \mathrm{y}$ is selected based on working hours of $8 \mathrm{~h} / \mathrm{d} \times 250 \mathrm{~d} / \mathrm{y}$ for the outdoor worker near the interim storage place.

\subsection{Analytical result for interim storage scenario}

Figure 2 presents the result of annual dose in four radioactive cesium concentration cases of $10,000 \mathrm{~Bq} / \mathrm{kg}$, $100,000 \mathrm{~Bq} / \mathrm{kg}, \quad 500,000 \mathrm{~Bq} / \mathrm{kg}$ and $\quad 700,000 \mathrm{~Bq} / \mathrm{kg}$ (existence ratio of ${ }^{134} \mathrm{Cs} /{ }^{137} \mathrm{Cs}=1.0$ ) for interim storage

Table 4. The number of times of transportation to restrict the annual dose to less than $1 \mathrm{mSv} / \mathrm{y}$.

\begin{tabular}{|l|c|c|c|c|c|}
\hline \multicolumn{2}{|c|}{ Type of transportation scenario } & \multicolumn{4}{|c|}{ The number of times of transportation to restrict the annual dose to less than $1 \mathrm{mSv} / \mathrm{y}$} \\
\cline { 2 - 6 } & $10,000 \mathrm{~Bq} / \mathrm{kg} * 1$ & $100,000 \mathrm{~Bq} / \mathrm{kg}$ & $500,000 \mathrm{~Bq} / \mathrm{kg}$ & $700,000 \mathrm{~Bq} / \mathrm{kg}$ \\
\hline \multirow{2}{*}{$\begin{array}{l}\text { Transportation to neighboring } \\
\text { farmland by a light truck }\end{array}$} & $\begin{array}{c}\text { Rolled straw } \\
\text { (Scenario I-A) }\end{array}$ & 384 & 38 & 7 & 5 \\
\cline { 2 - 6 } & $\begin{array}{l}\text { Compact straw } \\
\text { (Scenario I-B) }\end{array}$ & 243 & 24 & 4 & 3 \\
\hline $\begin{array}{l}\text { Transportation from remote } \\
\text { place to the northeastern area } \\
\text { in Japan by a heavy-duty } \\
\text { truck }\end{array}$ & $\begin{array}{c}\text { Rolled straw } \\
\text { (Scenario II-A) }\end{array}$ & 55 & 5 & 1 & $-* 2$ \\
\cline { 2 - 6 } & $\begin{array}{l}\text { Compact straw } \\
\text { (Scenario II-B) }\end{array}$ & 55 & 5 & 1 & - \\
\hline
\end{tabular}

(*1) Radioactive cesium concentration (existence ratio of ${ }^{134} \mathrm{Cs} /{ }^{137} \mathrm{Cs}=1.0$ ) in the straw

(*2) The dose is estimated to be $1.3 \mathrm{mSv}$ due to only one transportation and exceeds $1 \mathrm{mSv} / \mathrm{y}$.

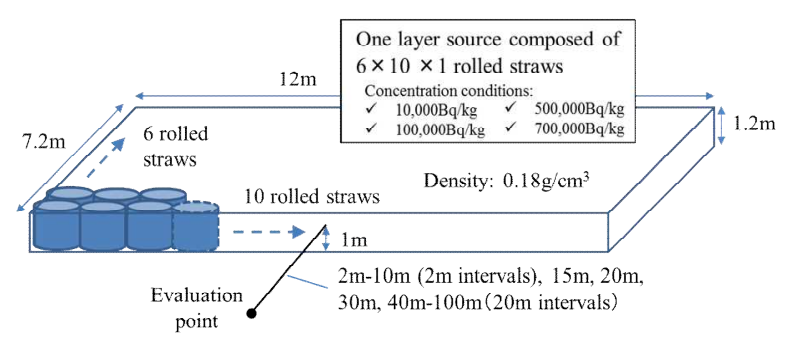

(a) One layer case

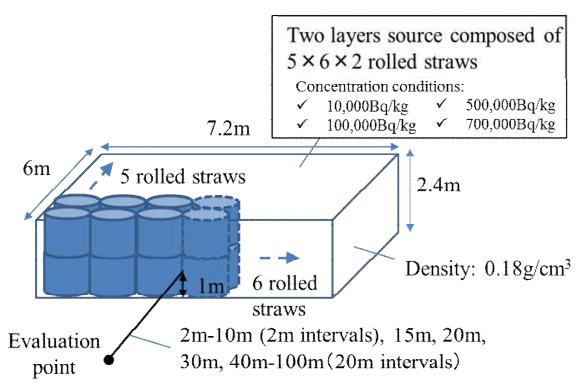

(b) Two layers case

Figure 1. Source configuration and analytical conditions in interim storage scenario. 
scenario. The annual dose in two layers case is higher than that in one layer case. The calculated results for interim storage scenario indicate that the distance to suppress the dose for the worker within $1 \mathrm{mSv} / \mathrm{y}$ is $10 \mathrm{~m}$ for $100,000 \mathrm{~Bq} / \mathrm{kg}$ and $30 \mathrm{~m}$ for $500,000 \mathrm{~Bq} / \mathrm{kg}$ and $700,000 \mathrm{~Bq} / \mathrm{kg}$.

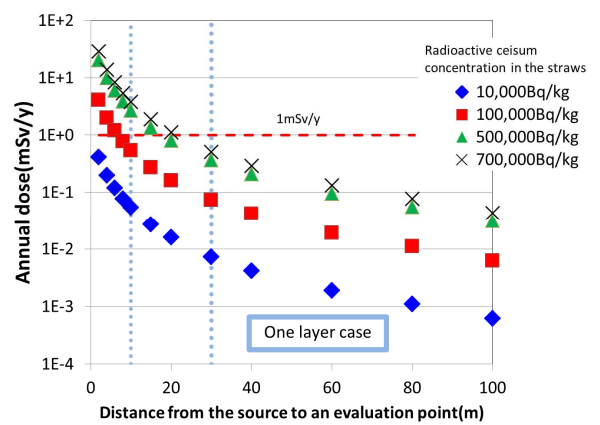

(a) One layer case

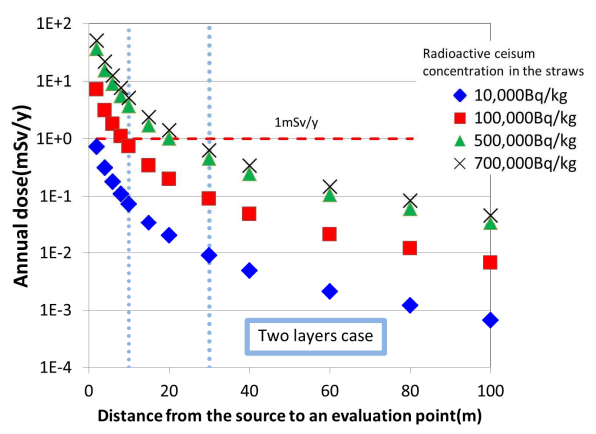

(b) Two layers case

Figure 2. Result of annual dose for interim storage scenario.

\section{Conclusion}

The rice straw contaminated by radioactive cesium was distributed to the market to feed beef cattle after the Fukushima Nuclear Plant accident. The doses for the dairy farmer should be decreased rapidly. In this study, dose analyses for the scenarios on transportation and interim storage of the straw were carried out to provide the Japanese government with their technical information. The result of transportation scenario suggests that the dose for the compact straws in the case of transportation to neighboring farmland is higher than that for the rolled straws, because of the higher dose for loading and unloading by hands than by an agricultural machine. The doses for transportation from remote place are about 5 times higher than that for transportation to neighboring farmland. These results lead to the criteria, that is, the number of times of transportation depending on the conditions of transport situation and straw shapes to restrict the annual dose to less than effective dose criterion of $1 \mathrm{mSv} / \mathrm{y}$ for four cesium concentration cases of $10,000 \mathrm{~Bq} / \mathrm{kg}, 100,000 \mathrm{~Bq} / \mathrm{kg}, \quad 500,000 \mathrm{~Bq} / \mathrm{kg}$ and $700,000 \mathrm{~Bq} / \mathrm{kg}$.
The calculated results for interim storage scenario indicate that the distance to suppress the dose for the worker within $1 \mathrm{mSv} / \mathrm{y}$ is $10 \mathrm{~m}$ for $100,000 \mathrm{~Bq} / \mathrm{kg}$ and $30 \mathrm{~m}$ for $500,000 \mathrm{~Bq} / \mathrm{kg}$ and $700,000 \mathrm{~Bq} / \mathrm{kg}$.

\section{Acknowledgements}

We would like to thank the Livestock Industry Department, Ministry of Agriculture, Forestry and Fisheries for providing us with appropriate information to set up some parameters used in safety assessment.

\section{R efer ences}

[1] Press Releases of Fukushima Prefecture, http://wwwcms.pref.fukushima.jp/download/1/chik usan_shinsai-gyuniku110718-1.pdf, July 18, 2011. [in Japanese]

[2] Special Committee on Radioactive Waste and Decommissioning, Radionuclide Concentrations for Materials not Requiring Treatment as Radioactive Wastes Generated from Dismantling etc. of Reactor Facilities and Nuclear Fuel U se Facilities, Nuclear Safety Commission of Japan (NSC), (2005). [in Japanese]

[3] Y. Sakamoto and S. Tanaka, QAD-CGGP2 and G33-GP2: Revised Versions of QAD-CGGP and G33-GP, JAERI-M 90-110, Japan Atomic Energy Research Institute (JAERI), (1990).

[4] H. Shindo, T. Marumoto and T. Higashi, Changes in elementary composition and distribution ratios of fractions in the decaying process of rice straw-calcium cyanamide mixture, J ournal of the Science of Soil and Manure, Japan 51(6), (1980), pp.497-502. [in Japanese]

[5] National Agriculture and Food Research Organization, Standard Tables of Feed Composition in Japan 2009, Japan Livestock Industry Association, (2009). [in Japanese]

[6] O. Enishi, K. Shijimaya and H. Ohta, Varietal differences in chemical composition and in vitro dry matter digestibility of rice (Lryza sativa L.) straw, Grassland Science 41, (1995), pp.152-155. [in Japanese]

[7] M. Watanabe, S. Takeda and H. Kimura, External Effective Dose Conversion Factors for Deriving Clearance Levels of Uranium and Transuranium Wastes, JAEA-Data/Code 2008-001, Japan Atomic Energy Agency (JAEA), (2008). [in Japanese]

[8] Nuclear Safety Commission of Japan (NSC), Near-term Policy to Ensure the Safety for Treating and Disposing Contaminated Waste around the Site of Fukushima Dai-ichi Nuclear Power Plants, NSC, June 3, (2011).

[9] J. F. Briesmeister (Ed.), M CNP - A General Monte Carlo N-Particle Transport Code, Version 4C, LA-13709-M, Los Alamos National Laboratory, (2000). 